\title{
The Role of Family Size in Personality Development of Twins in Five Cultural Zones of Haryana, India
}

\author{
Poonam Rani* and Bimla Dhanda
}

Department of Human Development and Family Studies, I.C. College of Home Science, CCSHAU, Hisar, Haryana - 125004, India

*Corresponding author

\section{A B S T R A C T}

\section{Keywords}

Personality, Family size, Culture, Traits, Behaviour Development, Emotional and cognitive growth

Article Info

Accepted:

24 August 2018

Available Online:

10 September 2018
Family size is defined in terms of the number of children in the household. The family is profoundly important to the developmental, emotional and cognitive growth of a child. Personality is defined as the characteristic set of behaviors, cognitions, and emotional patterns that evolve from biological and environmental factors. A pair of 200 twins in the age group of 3-6 years from five cultural zones of state Haryana was taken. Two variables were taken for the study. Family size was taken as independent variable and personality was taken as dependent variable. A Five Factor Personality Questionnaire (Cathy, 2011) was used for assessing the personality traits of preschool twins. Results revealed that personality was significant related to family size of the twins in Khadar $\left(\chi^{2}=4.30 *\right)$ zone. But the associations of personality was not significant related to family size of the twins in Bagar $\left(\chi^{2}=0.07\right)$, Nardak $\left(\chi^{2}=0.01\right)$, Mewat $\left(\chi^{2}=0.66\right)$ and Ahirwal $\left(\chi^{2}=1.20\right)$ zones.

\section{Introduction}

Family size may be considered from two perspectives. At the individual (micro) level, it defines one aspect of an individual's family background or environment.

As such, it represents a potential influence on the development and accomplishments of family members.

At the societal (macro) level, family size is an indicator of societal structure that may vary over time, with concomitant implications for individual development and social relations in different cohorts.
Family size is sometimes used to represent the total number of individuals comprising a family unit. In the present study, family size is defined in terms of the number of children in the household.

The family is the most important primary group in a society. It is the simplest and the most elementary form of society. The family as an institution is universal. It is the most permanent and the most pervasive of all social institutions.

The family is profoundly important to the developmental, emotional and cognitive growth of a child. Family is the single most 
important influence in a child's life. From their first moments of life, children depend on parents and family to protect them and provide for their needs. Parents and family form a child's first relationships.

Twins are nature's living laboratories. Twin studies have been a valuable source of information about the genetic basis of complex traits.

Personality and specific genes responsible for the ubiquitous heritability of personality traits has increasingly become a target for genetic research (Benjamin et al., 2002).

Identical and fraternal twins hold the keys to give understanding on personality traits. Identical (monozygotic) twins have essentially the same set of genes, while fraternal (or dizygotic) twins have, on average, a halfidentical set.

Personality traits, which can be described as differences between individuals regarding their behavior, thoughts, and feelings, can be seen as relatively stable in different situations and over time (Specht et al., 2014).

Personality is defined as the characteristic set of behaviors, cognitions, and emotional patterns that evolve from biological and environmental factors.

Personality traits are defined as the relatively enduring patterns of thoughts, feelings, and behaviors that differentiate individuals from one another and are elicited in trait affording situations (Roberts, 2009).

Personality has been approached in quite different ways by many theorists. Freud proposed that personality development is dependent upon early childhood experiences and largely determined by age five (Carver \& Scheier 2008).

\section{Objectives}

The present study aim is to find out the effect of family size on personality traits of twins in five cultural zones.

\section{Materials and Methods}

The study was conducted in five cultural zones of Haryana state namely Khadar, Bagar, Nardak, Mewat and Ahirwal. A pair of 200 twins (400 twins) in the age group of 3-6 years from different villages was assessed depending upon the availability of the twins were taken as sample. Two variables were taken for the study. Family size was taken as independent variable and personality was taken as dependent variable. A Five Factor Personality Questionnaire (Cathy, 2011) was used for assessing the personality traits of preschool twins.

\section{Results and Discussion}

\section{Associations of personality of twins with family size in five cultural zones}

Table 1 presented the associations of personality was significant related to family size of the twins in Khadar $\left(\chi^{2}=4.30 *\right)$ zone. But the associations of personality was not significant related to family size of the twins in Bagar $\left(\chi^{2}=0.07\right)$, Nardak $\left(\chi^{2}=0.01\right)$, Mewat $\left(\chi^{2}=0.66\right)$ and Ahirwal $\left(\chi^{2}=1.20\right)$ zones.

Personality traits are defined as the relatively enduring patterns of thoughts, feelings, and behaviors that differentiate individuals from one another and are elicited in trait affording situations (Roberts, 2009). Personality is a patterned body of habits, traits, attitudes and ideas of an individual as these are organized externally into roles and statuses and as they relate internally to motivation, goals and various aspects of selfhood (Sareen, 2015). 
Table.1 Associations of personality of twins with family size in five cultural zones

\begin{tabular}{|c|c|c|c|c|}
\hline \multirow[t]{2}{*}{ Variables } & \multicolumn{4}{|c|}{ Personality scores } \\
\hline & \multicolumn{4}{|c|}{ Bagar } \\
\hline Family Size & Low & High & Total & $\chi^{2}$ \\
\hline Small & 11(13.7) & $9(11.2)$ & $20(25.0)$ & \\
\hline Large & $35(43.7)$ & $25(31.2)$ & $60(75.0)$ & 0.07 \\
\hline \multirow[t]{2}{*}{ Total } & $46(57.5)$ & $34(42.5)$ & $80(100.0)$ & \\
\hline & \multicolumn{4}{|c|}{ Nardak } \\
\hline Family Size & Low & High & Total & $\chi^{2}$ \\
\hline Small & $8(10.0)$ & $6(7.5)$ & $14(17.5)$ & \\
\hline Large & $39(48.7)$ & $27(33.7)$ & $66(82.5)$ & 0.01 \\
\hline \multirow[t]{2}{*}{ Total } & $47(58.7)$ & $33(41.2)$ & $80(100.0)$ & \\
\hline & \multicolumn{4}{|c|}{ Khadar } \\
\hline Family Size & Low & High & Total & $\chi^{2}$ \\
\hline Small & $14(17.5)$ & $16(20.0)$ & $30(37.5)$ & \\
\hline Large & $35(43.7)$ & $15(18.7)$ & $50(62.5)$ & $4.30 *$ \\
\hline \multirow[t]{2}{*}{ Total } & $49(61.2)$ & $31(38.7)$ & $80(100.0)$ & \\
\hline & \multicolumn{4}{|c|}{ Mewat } \\
\hline Family Size & Low & High & Total & $\chi^{2}$ \\
\hline Small & $16(20.0)$ & $14(17.5)$ & $30(37.5)$ & \\
\hline Large & $22(27.5)$ & $28(35.0)$ & $50(62.5)$ & 0.66 \\
\hline \multirow[t]{2}{*}{ Total } & $38(47.5)$ & $42(52.5)$ & $80(100.0)$ & \\
\hline & \multicolumn{4}{|c|}{ Ahirwal } \\
\hline Family Size & Low & High & Total & $\chi^{2}$ \\
\hline Small & $15(18.7)$ & $19(23.7)$ & $34(42.5)$ & \\
\hline Large & $26(32.5)$ & $20(25.0)$ & $46(57.5)$ & 1.20 \\
\hline Total & $41(51.2)$ & $39(48.7)$ & $80(100.0)$ & \\
\hline
\end{tabular}

*Significant at $5 \%$ level of significance

Figures in parentheses indicate percentage

Personality traits, which can be described as differences between individuals regarding their behavior, thoughts, and feelings, can be seen as relatively stable in different situations and over time (Specht et al., 2014).

It was concluded that Personality was significantly related to family size of twins. Pollet et al., (2010) proposed that parents might be more strict and overprotective towards their first born children, than they children become more submissive in response and behaviors.

\section{References}

Ashton, M. C., Lee K. and Paunonen, S. V. 2002. What is the central feature of extraversion? Social attention versus reward sensitivity. Journal of Personality \& Social Psychology, 83:245-52.

Benjamin, J., Ebstein, R., and Belmaker, R. H. 2002. Molecular genetics of human personality. Washington, DC: American Psychiatric Press. Behavioral Scientist, 44:10-31. 
Blair C.2006. How similar are fluid cognition and general intelligence? A developmental neuroscience perspective on fluid cognition as an aspect of human cognitive ability. Behavior and Brain Sciences, 29: 109-125

Carver, C.S. and Scheier, M. F. 2008. Perspectives on Personality. Boston, MA: Allyn \& Bacon. 6th ed.

Depue, R. A. and Morrone-Strupinksy, J. V. 2005. A neurobehavioral model of affiliative bonding: implications for conceptualizing a human trait of affiliation. Behavior Brain Science, 28:313-395.

Evans, D. E. and Rothbart, M. K. 2007. Developing a model for adult temperament. Journal of Research Personality, 41:868-888.

Graziano, W. G., Habashi, M. M., Sheese, B. E. and Tobin, R. M. 2007. Agreeableness, empathy, and helping: a person X situation perspective. Journal Personality Social Psychology, 93:58399.

Jensen-Campbell, L. A., Adams, R., Perry, D. G., Workman, K. A., Furdella, J. Q. and Egan, S. K. 2002. Agreeableness, extraversion, and peer relations in early adolescence: winning friends and deflecting aggression. Journal of Research Personality, 36:224-51.

John, O. P., Naumann, L. P. and Soto, C. J. 2008. Paradigm shift to the integrative Big- Five trait taxonomy: History, measurement, and conceptual issues. In O. P. John, R. W. Robins, \& L. A. Pervin (Eds.), Handbook of personality: Theory and research (114-158). New York: Guilford Press.

Kaplan, S. C., Levinson, C. A. and Rodebaugh, T. L. 2012. Social Anxiety and the Big Five Personality Traits: The Interactive Relationship of Trust and Openness. Washington University in St. Louis.
Kesici S. 2007. Educational sciences: Theory and Practice. Journal of Humanities and Social Science, 7(3): 1325-1349.

Lamb, M. E., Chuang, S. S., Wessels, H., Broberg, A. G. and Hwang, C. P. 2002. Emergence and construct validation of the Big Five factors in early childhood: a longitudinal analysis of their ontogeny in Sweden. Child Development, 73:1517-24.

Lucas, R. E., Diener, E., Grob, A., Suh, E. M. and Shao, L. 2000. Cross-cultural evidence for the fundamental features of extraversion. Journal of Personality \& Social Psychology, 79:452-68.

Malekpour, M. 2007. Effects of attachment on early and later development. The British Journal of Developmental Disabilities, 53(105): 81-95.

McAdams, Dan. P. and Pals, J. L. 2006. A new Big Five: Fundamental principles for an integrative science of personality. American Psychologist, 61(3): 204-217.

McCrae, R. R. 2002. Cross-Cultural Research on the Five-Factor Model of Personality. Readings in Psychology and Culture, 4(4):1-12.

Perunovic, M. 2007. Agreeableness and Close Relationships: Is It Trust That Really Matters? Ph.D. Dissertation. University of Waterloo.

Robert, P. C., Haworth, M. A. and Philip, D. 2008. A Twin Study into the Genetic and Environmental Influences on Academic Performance in Science in nine-year-old Boys and Girls. International Journal of Science Education. 30(8): 1003.

Sareen, S. 2015. Johari Window: An Important Model for Personality Development. Gene -International Journal of Management Research. 3(4):13-18.

Scollon, C. N. and Diener, E. 2006. Love, work, and changes in extraversion and neuroticism over time. Journal of 
Personality and Social Psychology, 91: 1152-1165.

Specht J., Bleidorn W., Denissen J. J. A., Hennecke M., Hutteman R. and Kandler C. 2014. What drives adult personality development? A comparison of theoretical perspectives and empirical evidence. European Journal of Personality, 28: 216-230.
Terracciano, A., Costa, P. T. and McCrae, R. R. 2006. Personality plasticity after age 30. Personality and Social Psychology Bulletin, 32:999-1009.

Whiteman, S., McHale, S. and Soli, A. 2011. Theoretical perspectives on sibling relationships. Journal of Family Theory \& Review, 3(2): 124-139.

\section{How to cite this article:}

Poonam Rani and Bimla Dhanda. 2018. The Role of Family Size in Personality Development of Twins in Five Cultural Zones of Haryana, India. Int.J.Curr.Microbiol.App.Sci. 7(09): 32213225. doi: https://doi.org/10.20546/ijcmas.2018.709.400 